\title{
Survei tentang standar fasilitas pembelajaran di SMK Pasundan 1 Bandung
}

\author{
(Survey about the standard of learning facilities at SMK Pasundan 1 \\ Bandung)
}

\author{
Annisa Meidita Yuritami Putri', Sambas Ali Muhidin²* \\ ${ }^{1.2}$ Program Studi Pendidikan Manajemen Perkantoran, \\ Fakultas Pendidikan Ekonomi dan Bisnis, Universitas Pendidikan Indonesia, \\ JI. Dr. Setiabudhi, No. 229 Bandung, Jawa Barat Indonesia \\ Email : sambas@upi.edu
}

\begin{abstract}
ABSTRAK
Hasil belajar siswa dipengaruhi oleh banyak faktor, diantaranya fasilitas pembelajaran. Penelitian tentang kedua variabel tersebut, yaitu fasilitas pembelajaran dan hasil belajar telah banyak dilakukan, baik yang mengkaji secara parsial maupun mengkaji keduanya dalam analisis hubungan (korelasi). Salah satunya adalah kajian ini yang mencoba menyajikan hasil penelitian mengenai hubungan fasilitas pembelajaran dengan hasil belajar siswa pada SMK Swasta yang berlokasi di kota Bandung. Penelitian ini menggunakan metode survei, sementara data yang dikumpulkan melalui terhadap 60 orang siswa kelas XII Jurusan Administrasi Perkantoran, dianalisis melalui analisis korelasi untuk variabel nominalnominal, yaitu untuk melihat: (1) untuk mencari bukti terdapat tidaknya hubungan fasilitas pembelajaran dengan hasil belajar siswa, (2) bila sudah ada hubungan, untuk melihat besar kecilnya hubungan fasilitas pembelajaran dengan hasil belajar siswa, dan (3) untuk memperoleh kejelasan dan kepastian apakah hubungan tersebut berarti (meyakinkan/signifikan) atau tidak berarti (tidak meyakinkan). Berdasarkan hasil analisis korelasi, diperoleh hasil bahwa ada hubungan antara fasilitas pembelajaran dengan hasil belajar siswa.
\end{abstract}

Kata kunci: fasilitas pembelajaran, hasil belajar

\section{ABSTRACT}

The outcomes of student learning are influenced by many factors, including the learning facilites. Research on these two variabels about learning facility and learning outcomes are usually found in some cases, either partially or simultaneously analyze about the relationship (correlation). The study tries to present the results of research on the relationship of learning facilities with student learning outcomes in vocational school located in the city of Bandung. This study used explanatory survey method with collects data from 60 students from class XII of Office Administration Departement, analyzed through the correlation analysis for nominal variable, to: (1) to find evidence whether there is any correlation between teaching facilities and student learning outcomes, (2) when there is a correlation, to see the amount of correlation between learning facilities and student learning

Received: Agustus 2017, Revision: November 2017, Published: Januari 2018

* Corresponding author

Copyright @ 2018, EISSN 2656-4734 
outcomes, and (3) to make sure whether the correlation has any meaning (convincing/significant) or meaningless (inconclusive). Based on the results of correlation analysis, the result is that there is a correlation between learning facilities and student learning outcomes.

Keyword: learning facilities, learning outcomes

\section{PENDAHULUAN}

Fakta tentang rendahnya mutu pendidika dan daya saing tersebut terjadi bukan tanpa sebab. Kondisi rendahnya mutu pendidikan ini dipicu oleh banyak faktor baik internal maupun eksternal. Salah satu faktor masalah utama dalam pendidikan adalah rendahnya kualitas fasilitas pembelajaran.

Permasalahan terkait tentang fasilitas pembelajaran sama rumitnya dengan permasalahan pendidikan itu sendiri, karena fasilitas pembelajaran meliputi semua sarana dan prasarana yang diperlukan dalam proses belajar mengajar baik yang bergerak maupun tidak bergerak agar pencapaian tujuan pembelajaran dapat berjalan lancar, teratur, efektif dan efisien sehingga seorang guru dapat melaksanakan kegiatan pembelajran dengan kinerja yang baik dan siswa dapat memperoleh hasil pembelajaran yang maksimal. Apabila fasilitas pembelajaran telah sesuai standar yang ditentukan oleh Peraturan Pemerintah no. 40 tahun 2008 tentang standar sarana dan prasarana di SMK maka dapat dikatakan bagus sesuai dengan standar. Fenomena fasilitas pembelajaran muncul dalam bentuk sarana dan prasarana yang ada disekolah yang dapat menggambarkan bagaimana hasil belajar siswa.

Jika ditarik dari permasalahan rendahnya mutu pendidikan, maka secara teori, fasilitas pembelajaran memiliki hubungan dengan hasil belajar siswa. Dengan demikian dapat dikatakan bahwa fasilitas pembelajaran dapat berpengaruh terhadap hasil belajar siswa. Jika fasilitas pembelajaran disekolah belum sesuai dengan standar maka hasil belajar siswa dapat dikatakan rendah. Begitupun sebaliknya, jika fasilitas pembelajaran disekolah telah dikatakan bagus dan sesuai dengan standar maka hasil belajar siswa dapat dikatakan tinggi. Oleh karena itu perlu dilakukan analisis sehingga dijadikan kajian dalam penelitian ini.

Bedasarkan hal tersebut rumusan masalah dari penelitian ini adalah "adakah hubungan gambaran fasilitas pembelajaran dengan hasil pembelajaran siswa?". dengan demikian tujuan dari penelitian ini adalah untuk menganalisis gambaran fasilitas pembelajaran dengan hasil belajar siswa.

\section{TINJAUAN PUSTAKA}

\section{Fasilitas Pembelajaran}

Secara arti kata, fasilitas pembelajaran dalam Kamus Besar Bahasa Indonesia berarti segala sesuatu yang dipakai sebagai alat dalam mencapai maksud dan tujuan penunjang terselenggaranya suatu proses. Berdasarkan arti kata tersebut, maka fasilitas pembelajaran dapat didefinisikan sebagai semua sarana dan prasarana yang diperlukan dalam proses belajar mengajar baik yang bergerak maupun tidak bergerak agar pencapaian tujuan pembelajaran dapat berjalan lancar, teratur, efektif dan efisien sehingga seorang guru dapat melaksanakan kegiatan pembelajaran yang maksimal (Annurahman 2010).

Dijelaskan pula prasarana pendidikan adalah fasilitas yang secara tidak langsung menunjang jalannya proses pendidikan atau pengajaran, seperti halaman, kebun,taman sekolah, jalan menuju 
sekolah tetapi jika dimanfaatkan secara langsung untuk proses belajar mengajar, komponen tersebut merupakan sarana pendidikan (Mulyasa 2005).

Bagus atau tidaknya fasilitas pembelajaran dapat diukur dengan melihat beberapa indikator melalui (Annurahman 2010):

1. Keadaan Gedung Sekolah

Menurut Undang-undang Republik Indonesia nomor 28 tahun 2002 tentang bangunan gedung yang dimaksud prasarana dan sarana bangunan gedungadalah fasilitas kelengkapan didalam dan diluar bangunan gedung yang mendukung pemenuhan terselenggaranya fungsi bangunan gedung. Fungsi bangunan gedung sekolah adalah terselenggaranya proses pendidikan. Bedasarkan undang-undang persyaratan bangunan gedung meliputi persyaratan administrative dan persyaratan teknis. Persyaratan administratif meliputi hak atau izin atas tanah, status kepemilikan dan izin mendirikan bangunan. Persyaratan tata bangunan yang merupakan persyaratan teknis diatur dalam Undang-undang Republik Indonesia Nomor 28 Tahun 2002 pasal 9 ayat 1 meliputi persyaratan peruntukan dan intensitas bangunan gedung, arsitektur bangunan gedung, dan persyaratan pengendalian dampak lingkungan. Secara garis besar penataan gedung sekolah meliputi kenyamanan gedung yang berkaitan dengan intensitas atau lokasi bangunan gedung dan kelayakan gedung yang berkaitan dengan arsitektur bangunan gedung.

2. Kualitas Ruang Kelas

Ruang kelas merupakan bagian dari gedung sekolah yang kuantitas dan kualitasnya perlu diperhatikan oleh instasi sekolah. Undang-undang Republik Indonesia Nomor 28 tahun 2002 pasal 23 mengatur tentang pencahayaan ruang pada gedung. "Sistem pencahayaan merupakan kebutuhan pencahayaan yang harus diadakan melalui pencahayaan alami dan atau pencahayaan buatan, termasuk pencahayaan darurat". Pencahayaan yang baik diruang kelas akan memperlancar proses pembelajaran. Selain pencahayaan, kenyamanan ruang kelas juga perlu diperhatikan. Hal ini juga diatur dalam Undang-undang Republik Indonesia Nomor 28 tahun 2002 pasal 26 bahwa "persyaratan kenyamanan bangunan gedung meliputi kenyamanan ruang gerak dan hubungan antar ruang, pandangan, serta tingkat getaran dan tingkat kebisingan". Kenyamanan kondisi udara dalam ruang merupakan tingkat kenyamanan yang diperoleh dari temperatur dan kelembapan didalam ruang untuk terselenggaranya proses belajar mengajar.

3. Keberfungsian Perpustakaan

Dalam Undang-undang Republik Indonesia Nomor 43 Tahun 2007 tentang perpustakaan dinyatakan bahwa perpustakaan adalah "Instansi pengelola koleksi karya tulis, karya cetak, dan/atau karya rekam secara profesioanal dengan sistem yang baku guna memenuhi kebutuhan pendidikan, penelitian, pelestarian, informasi, dan rekreasi para pemustaka". Tujuan utama penyelenggaraan perpustakaan sekolah adalah meningkatkan mutu pendidikan bersama-sama dengan unsur-unsur sekolah lainnya. Sedangkan tujuan lainnya adalah menunjang, mendukung, dan melengkapi semua kegiatanbaik kurikuler, ko-kulikuler ekstrakulikuler, di samping dimaksudkan pula dapat membantu menumbuhkan minat dan mengembangkan bakat murid serta memantapkan strategi belajar mengajar. (Mujianti 2010. Secara operasional tujuan perpustakaan sekolah bila dikaitkan dengan pelaksanaan program diantaranya adalah: (1) Memupuk rasa cinta kesadaran dan kebiasaan membaca, (2) Membimbing dan mengarahkan teknik memahami isi bacaan, (3) Memperluas pengetahuan para siswa, (4) Membantu mengembangkan kecakapan berbahasa dan daya pikir para siswa dengan menyediakan bahan bacaan yang bermutu, (5) Membimbing para siswa agar dapat menggunakan dan memelihara bahan pustaka dengan baik, 
(6) Memberikan dasar-dasar ke arah studi mandiri, (7) Memberikan kesempatan kepada para siswa untuk belajar bagaimana cara menggunaan perpustakaan dengan baik, efektif dan efisien, terutama dalam menggunakan bahan-bahan refrensi, (8) Menyediakan bahan-bahan pustaka yang menunjang pelaksanaan program kurikulum di sekolah.

4. Keberfungsian Fasilitas Kelas dan Laboratorium

Menurut ensiklopedia ruang belajar adalah suatu ruangan tempat kegiatan belajar mengajar dilangsunkan. Ruang belajar terdiri dari beberapa jenis sesuai fungsinya yaitu: ruang kelas atau ruang tatap muka, ruang ini berfungsi sebagai ruangan tempat siswa menerima pelajaran melalui proses interaktif antara peserta didik dengan pendidik, ruang belajar terdiri dari berbagai ukuran dan fungsi. Sistem kelas terbagi dua jenis yaitu kelas berpindah (moving class) dan kelas tetap. Selain ruang kelas, ruang belajar terdiri dari ruang praktik atau laboratorium yaitu ruang yang berfungsi sebagai ruang tempat peserta didik menggali ilmu pengetahuan dan meningkatkan keahlian melalui praktik, latihan, penelitian, percobaan,. Ruang ini mempunyai kekhususan dan diberi nama sesuai kekhususannya tersebut, diantaranua adalah laboratorium komputer, laboratorium bahasa, laboratorium mengetik, laboratorium perkantoran, ruang keterampilan, dan lain-lain (Wikipedia Bahasa Indonesia). Laboratorium adalah tempat belajar mengajar melalui metode praktikum yang dapat menghasilkan pengalaman belajar dimana siswa berinteraksi berbagai alat dan bahan untuk mengobservasi gejala-gejala yang dapat diamati secara langsung dan membuktikan sendiri sesuatu yang dipelajari jadi suatu laboratorium sekolah mempunyai peranan yang sangat penting dalam upaya meningkatkan mutu serta sistem pengajaran disekolah. Keberfungsian fasilitas kelas berkaitan denganjumlah kursi dan meja belajar serta keberhasilan kelas. Keberfungsian laboratorium berkaitan dengan fungsi alat-alat di laboratorium seperti mesin tik, komputer, internet, dan alat atau mesin perkantoran.

5. Ketersediaan Buku Pelajaran

Fungsi buku pelajaran bagi siswa adalah sebagai sarana kepastian tentang apa yang dipelajari, alat kontrol untuk mengetahui seberapa banyak dan seberapa jauh siswa menguasai matei pelajaran, alat belajar dimana siswa dapat menemukan petunjuk, teori, maupun konsep dan bahan-bahan latihan atau evaluasi. Penyusunan buku pelajaran dalam upaya pengembangan pembelajaran di sekolah disusun dengan fungsi yang jelas. Fungsi dan peranan buku pelajaran adalah: (a) mencerminkan suatu sudut pandang yang tangguh dan modern mengenai pelajaran serta mendemonstrasikan aplikasinya dalam bahan pengajaran yang disajikan, (b) menyajikan suatu sumber pokok masalah yang kaya, mudah dibaca dan bervariasi yang sesuai dengan minat dan kebutuhan para siswa, sebagai dasar bagi program-program kegiatan yang disarankan dimana keterampilan-keterampilan ekspresional diperoleh dibawah kondisi-kondisi yang menyerupai kehidupan yang sebenarnya, (c) menyediakan suatu sumber yang tersusun rapi dan bertahap mengenai keterampilan-keterampilan ekspresional yang mengemban masalah pokok dalam komunikasi, (d) metode dan saran penyajian bahan buku teks harus memenuhi syaratsyarat tertentu. Misalnya harus menarik, menantang, merangsang, bervariasi sehingga siswa benar-benar termotivasi untuk mempelajari buku menyajikan fiksasi awal yang perlu dan penunjang bagi latihan-latihan dan tugas-tugas praktis, (f) disamping sebagai sumber bahan buku pelajaran juga berperan sebagai sumber atau alat relevansi dan pengajaran remedial yang serasi dan tepat guna (Green dan Petty) dalam (Annurahman, 2010, hlm. 198).

6. Optimalisasi Media atau Alat Bantu 
Media atau alat bantu dapat diartikan sebagai segala sesuatu yang dapat dipergunakan untuk menyalurkan pesan, merangsang pikiran, perasaan, perhatian, dan keamanan siswa, sehingga dapat terdorong terlihat dalam proses pembelajaran. Perangkat media pembelajaran atas hardware dan software. Istilah ini tidak hanya dipakai dalam dunia komputer, tetapi juga untuk semua jenis media pembeljaran. Contoh, isi pesan yang disiimpan dalam transparansi OHP, kaset audio, kaset video, film slide. Software adalah adalah isi pesan yang disimpan dalam material, sedangkan hardware adalah peralatan yang digunaan untuk menyampaikan pesan yang telah dituangkan ke dalam material untuk dikirim ke audiens. Contoh, proyektor overhead, proyektor film, video tape recorder, proyektor slide, proyektor filmstrip. Karakteristik dari media atau alat bantu pembelajaran bermacam-macam, ada yang berupa dua dimensi yang biasanya menggunakan papan tulis tiga dimensi yang menggunakan benda hidup atau mati dan audio visual yang menggunakan infokus. pada masa sekarang, media yang sering digunakan adalah audio visual yang disajikan melalui infokus. Keberfungsian infokus pada masa sekarang sangat berarti karena berperan untuk menyajikan materi-materi pelajaran dan membuat tertarik siswa. Dengan adanya infokus, guru dapat menyajikan pelajaran yang dirancang berupa slide, film, informasi dari internet dan contoh peraga dengan mudah.

\section{Hasil Belajar}

Hasil belajar merupakan hal yang berhubungan dengan kegiatan belajar karena kegiatan belajar merupakan proses sedangkan hasil belajar adalah sebagian hasil yang dicapai seseorang setelah mengalami proses belajar dengan terlebih dahulu mengadakan evaluasi dari proses belajar yang dilakukan. Untuk memahami pengertian hasil belajar maka harus bertitik tolak dari pengertian belajar itu sendiri. Belajar adalah serangkaian kegiatan jiwa raga untuk memperoleh suatu perubahan tingkah laku sebagai hasil dari pengalaman individu dalam interaksi dengan lingkungannya menyangkut kognitif, afektif, dan psikomotorik (Djamarah 2002).

Salah satu indikator tercapai atau tidaknya suatu proses pembelajaran adalah dengan melihat hasil belajar yang dicapai oleh siswa. Hasil belajar merupakan cerminan tingkat keberhasilan atau pencapaian tujuan dari proses belajar yang telah dilaksanakan yang pada puncaknya diakhiri denga suatu evaluasi. Hasil belajar merupakan realisasi atau pemekaran dari kecakapankecakapan potensial atau kapasitas yang dimiliki seseorang (Sukmadinata 2007). Dijelaskan pula hasil belajar sebagai hasil yang telah dicapai seseorang setelah mengalami proses belajar dengan terlebih dahulu mengadakan evaluasi dari proses belajar yang dilakukan (Arikunto 2010). Ada tiga macam hasil belajar, yakni (a) Keterampilan dan kebiasaan, (b) pengetahuan dan pengertian, (c) sikap dan cita-cita (Howard Kingsley dalam Sudjana 2013). Hasil belajar sebagai salah satu indikator pencapaian tujuan pembelajaran di kelas tidak terlepas dari faktor-faktor yang mempengaruhi hasil belajar itu sendiri. untuk mencapai hasil belajar siswa sebgaimana yang diharapkan, maka perlu diperhatikan beberapa faktor yang mempengaruhi hasil belajar antara lain faktor yang berasal dari dalam diri anak adalah (a) Faktor jasmaniah (fisiologi) yang meliputi: kondisi fisik dan panca indera. (b) Faktor psikologi yang meliputi: bakat, minat, kecerdasan, motivasi, dan kemampuan kognitif. Faktor yang berasal dari luar diri anak antara lain adalah (a) Faktor lingkungan yang meliputi: alam dan sosial (b) Faktor instrumental yang meliputi: kurikulum atau bahan pelajaran, guru atau pengajar, sarana atau fasilitas dan administrasi atau manajemen (Ngalim Purwanto 2009). 
Dari keseluruhan uraian yang dikemukakan di atas, maka dapat dibuat model hubungan variabel dan hipotesis penelitian sebagai berikut:

Fasilitas Pembelajaran

(Variabel X)

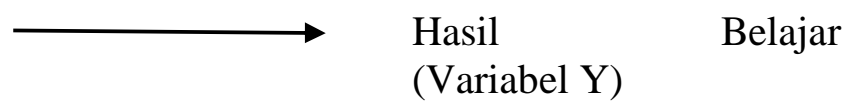

Gambar 1. Hubungan antara Variabel X dan Variabel Y

Keterangan:

Variabel X : Fasilitas Pembelajaran

Variabel Y : Hasil Uji Kompetensi

: Hubungan Variabel X dan Variabel Y

Pengajuan hipotesis pada penelitian ini adalah sebagai berikut:

$\mathrm{H}_{\mathrm{o}}$ : Tidak ada hubungan antara fasilitas pembelajaran dengan hasil belajar siswa

$\mathrm{H}_{1}$ : Ada hubungan antara fasilitas pembelajaran dengan hasil belajar siswa

\section{METODOLOGI}

Penelitian ini menggunakan metode survey. Responden adalah siswa Sekolah Menengah Kejuruan Swasra Kota Bandung, Provinsi Jawa Barat, Indonesia sebanyak 60 orang. Berdasarkan metodenya, penelitian ini merupakan penelitian survei, yaitu penelitian yang dilakukan terhadap sejumlah individu atau unit analisis, sehingga ditemukan fakta atau keterangan secara faktual mengenai gejala suatu kelompok atau perilaku individu, dan hasilnya dapat digunakan sebagai bahan pembuat rencana atau pengambilan keputusan. Penelitian survei ini merupakan studi yang bersifat kuantitatif dan umumnya menggunakan kuesioner sebagai alat pengumpul datanya. Sementara jika dilihat berdasarkan tujuan penelitian, maka penelitian ini termasuk kedalam penelitian verifikatif, yaitu penelitian yang bertujuan untuk melakukan pengujian terhadap suatu fenomena dengan teori yang sudah ada. (Uep dan Sambas, 2011, hlm. 5-6).

Implikasi metode penelitian survei verifikatif ini adalah alat pengumpul data berupa kuesioner yang dibuat, disebarkan kepada siswa yang berada pada SMK Swasta di Kota Bandung, sebagai unit analisisnya, yang berjumlah 60 orang. Dengan demikian penelitian ini merupakan penelitian sampel. Selain itu teknik analaisis data menggunakan bantuan statistik, sebagai alat untuk menguji/memverifikasi proposisi hipotetik yang sudah dibuat, yaitu menguji ada tidaknya hubungan fasilitas pembelajaran dengan hasil belajar siswa. Berkaitan dengan tujuan tersebut, maka teknik analisis data yang digunakan adalah analisis chi square.

\section{HASIL PENELITIAN}

\section{Fasilitas Pembelajaran}

Instrumen yang dikembangkan pada variabel fasilitas pembelajaran, dibentuk oleh indikator Keadaan Gedung Sekolah, Keadaan Ruang Kelas, Keadaan Fasilitas Kelas dan Laboratorium, Optimalisasi Media/ Alat Bantu. Semua indikator tersebut diarahkan untuk mengukur hubungan gambaran fasilitas pembelajaran dengan hasil pembelajaran siswa.

Secara umum gambaran fasilitas pembelajaran dengan hasil pembelajaran siswa SMK Swasta di Kota Bandung, jika dilihat berdasarkan kriteria yang ada pada Tabel 1. Kriteria Gambaran Variabel Fasilitas Pembelajaran, ada pada kategori baik sesuai standar. Hasil peelitian 
tersebut memberikan informasi bahwa secara keseluruhan fasilitas pembelajaran pada SMK Swasta di Kota Bandung berada pada kategori baik sesui standar. Artinya bahwa secara keseluruhan sudah bagus, sudah sesuai standar fasilitas pembelajaran sesuai Peraturan Pemerintah no. 40 tahun 2008.

Tabel 1. Kriteria Gambaran Variabel Fasilitas Pembelajaran

\begin{tabular}{|l|c|c|}
\hline \multicolumn{1}{|c|}{ Indikator } & Presentase (\%) & Kategori \\
\hline Keadaan Gedung Sekolah & 100 & Sesuai Standar \\
\hline Keadaan Ruang Kelas & 93 & Baik \\
\hline Keadaan Fasilitas Kelas \& Laboratorium & 87 & Baik \\
\hline Optimalisasi Media/Alat Bantu & 94 & Baik \\
\hline
\end{tabular}

Sumber: Data terolah

Bedasarkan tabel diatas, jika dilihat dari indikator-indikator yang membentuk variabel fasilitas pembelajaran, indikator keadaan gedung sekolah memiliki presentasi tertinggi yaitu $100 \%$, jika dibandingkan dengan inikator lainnya. Sementara presentasi terendah dimiliki oleh keadaan fasilitas kelas \& laboratorium yaitu $87 \%$. Hasil ini menunjukkan bahwa keadaan gedung sekolah sudah sesuai standar peraturan pemerintah no. 40 tahun 2008 dibandingkan indikator lainnya. Sedangkankan indikator keadaan fasilitas kelas \& laboratorium dipersepsi oleh responden tidak banyak memberikan peran dalam fasilitas pembelajaran yang dimiliki SMK Swasta di Kota Bandung.

\section{Hasil Belajar Siswa}

Variabel hasil belajar diperoleh dari nilai uji kompetensi siswa di SMK Swasta di Kota Bandung. Tabel berikut adalah nilai hasil belajar siswa.

Secara umum hasil belajar siswa melalui nilai uji kompetensi siswa SMK Swasta di Kota Bandung, jika dilihat berdasarkan kriteria yang ada pada Tabel 2. Kriteria Gambaran Variabel Hasil Belajar, ada pada kategori tinggi. Hasil penelitian tersebut, memberikan informasi bahwa secara keseluruhan, hasil belajar siswa SMK Swasta di Kota Bandung berada pada kategori tinggi. Artinya bahwa nilai hasil belajar siswa melalui nilai uji kompetensi siswa sudah sangat baik.

Tabel 2. Kriteria Gambaran Variabel Hasil Belajar Siswa

\begin{tabular}{|l|c|c|}
\hline \multicolumn{1}{|c|}{ Ukuran Variabel } & Interval Skor & Presentase (\%) \\
\hline Tinggi & $100-85$ & 75 \\
\hline Sedang & $85-75$ & 15 \\
\hline Rendah & $75-0$ & 10 \\
\hline
\end{tabular}

Sumber: Data Terolah

Sementara secara rinci dengan melihat indikator-indikator yang membentuk variabel hasil belajar siswa, gambaran tingkat hasil belajar siswa pada tabel berikut. 
Tabel 3. Gambaran Hasil Belajar Siswa SMK Swasta di Kota Bandung

\begin{tabular}{|l|c|c|}
\hline & Presentase $(\%)$ & Kategori \\
\hline Mengetik & 96,6 & Tinggi \\
\hline Surat & 98 & Tinggi \\
\hline PPT & 98,8 & Tinggi \\
\hline Internet & 99,8 & Tinggi \\
\hline Rapat & 99,5 & Tinggi \\
\hline Telepon & 99,7 & Tinggi \\
\hline Kas Kecil & 98,5 & Tinggi \\
\hline Arsip & 99,3 & Tinggi \\
\hline Agenda & 97 & Tinggi \\
\hline
\end{tabular}

Sumber: Data terolah

Berdasarkan tabel 3 di atas, jika dilihat dari indikator-indikator yang mebentuk variabel hasil belajar, indikator internet memiliki presentase tertinggi yaitu 99,8\%, jika dibandingkan dengan indikator lainnya. Sementara presentasi terendah dimiliki oleh indikator mengetik yaitu 96,6\%. Semua indikator yang diperoleh dari nilai hasil uji kompetensi siswa pada kategori tinggi. Artinya bahwa hasil belajar yang diperoleh siswa melalui uji kompetensi siswa pada kategori tinggi.

\section{PENGUJIAN HOPOTESIS}

Hipotesis yang hendak diuji dalam penelitian ini meliputi: (1) Adakah hubungan gambaran fasilitas pembelajaran dengan hasil belajar siswa di SMK Swasta di Kota Bandung.

Untuk melihat hubungan fasilitas pembelajaran dengan hasil belajar siswa, penulis menggunakan analisis korelasi chi square. Diperoleh hasil pada variabel fasilitas pembelajaran (X) dengan $\mathrm{db}=16$ pada $\mathrm{a}=0,05 \mathrm{rt}_{\text {abel }}=28,2962$ dan $\mathrm{r}_{\text {hitung }}$ sebesar 42,71057. Dengan demikian, nilai $\mathrm{r}_{\text {hitung }}>$ nilai $\mathrm{rt}_{\mathrm{abel}}=42,71057>28,2962$, dengan demikian nilai uji chi square berada di daerah penolakan $\mathrm{H}_{0}$. Seperti ilustrasi berikut:

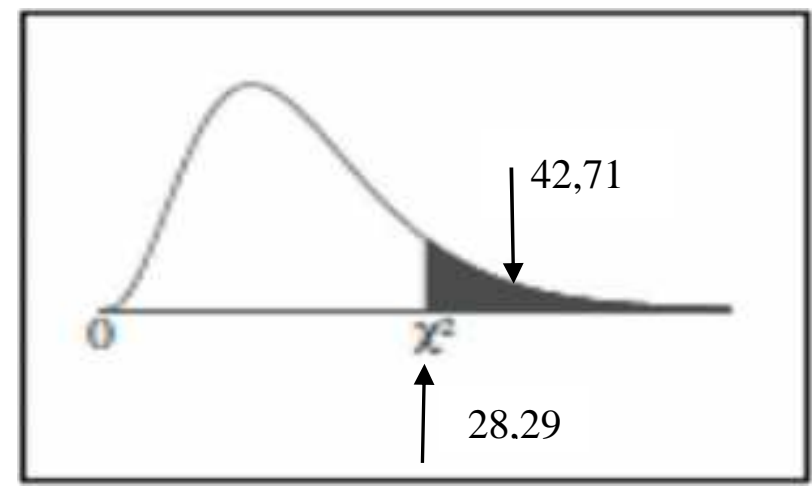

Gambar 2.

$\mathrm{rt}_{\mathrm{abel}}=42,71057>28,2962$, dengan demikian nilai uji chi square berada di daerah penolakan $\mathrm{H}_{0}$. 
Kesimpulan statistik: Berdasarkan hasil survei terhadapa 60 responden yang dipilih secara cross section, diperoleh indikasi objektif bahwa ada hubungan fasilitas pembelajaran dengan hasil belajar siswa. Kesimpilan penelitian: Ada hubungan positif antara fasilitas pembelajaran dengan hasil belajar siswa.

\section{KESIMPULAN}

Fasilitas pembelajaran pada Sekolah Menengah Kejuruan (SMK) Swasta di Kota Bandung berada pada kategori baik sesuai standar yang diukur melalui empat indikator yaitu indikator Keadaan Gedung Sekolah, Keadaan Ruang Kelas, Keadaan Fasilitas Kelas dan Laboratorium, Optimalisasi Media/ Alat Bantu. Sementara hasil belajar siswa SMK Swasta di Kota Bandung berada pada kategori tinggi, yang diperoleh dari nilai hasil uji kompetensi meliputi yaitu mengetik, surat, PPT, internet, rapat, telepon, kas kecil, arsip, agenda.

Selanjutnya hubungan fasilitas pembelajaran dengan hasil belajar siswa SMK Swasta di Kota Bandung, berhubungan secara positif dan signifikan. Artinya jika fasilitas pembelajaran disekoalh baik sesui dengan standar, maka hasil belajar siswa tinggi begitupun sebaliknya. Terkait fasilitas pembelajaran dengan hasil belajar siswa, diperoleh kesimpulan terdapat hubungan fasilitas pembelajaran dengan hasil belajar siswa pada SMK Swasta di Kota Bandung.

\section{DAFTAR PUSTAKA}

Abdurahman, M., Sambas A.M., \& Somantri, A. (2011). Dasar-Dasar Metode Statistika. Bandung: CV Pustaka Setia.

Annurahman. (2010). "Belajar dan Pembelajaran”. Bandung: Alfabeta

Arikunto, Suharsimi. (2011). Dasar-dasar evaluasi pendidikan evaluasi pendidikan. Edisi revisi cetakan kesebelas. Jakarta: Bumi Aksasra.

Djamarah. (2002). "Strategi belajar mengajar”. Jakarta: Rineka Cipta.

Muhidin, Sambas A. \& Somantri, A. (2006). Aplikasi Statistika. Bandung: CV Pustaka Setia.

Mulyasa, E. (2005). "Manajemen Berbasis Sekolah: Konsep, Strategi dan Implementasi". Bandung: Remaja Rosda Karya.

Ngalim Purwanto. (2009). Evaluasi Hasil Belajar. Yogyakarta: Pustaka Pelajar. 